\title{
Indonesian Student Perception in Digital Payment
}

\author{
Aldilla Iradianty ${ }^{(1)}$ \\ Bayu Rima Aditya (2) \\ Telkom University ${ }^{(1)(2)}$ \\ aldillai@telkomuniversity.ac.id ${ }^{(1)}$
}

\begin{abstract}
The trend of using digital payment in Indonesia is increasing every year. Most people have been felt the benefit of Digital Payment service. This research provide perspective about awareness, perceptions and preferences of students in Indonesia towards digital paymentbased payment system. This quantitative research involved 104 students from various universities in Indonesia. The information collected by a questionnaire and was analyzed by descriptive statistical techniques. The result of this study indicate that the awareness of students in Indonesia about digital payment services is very high. The convenience of using this service, the availability of services, discounts and reward points are the main factors that influence them in choosing digital payment service. This research also show that the majority of students prefer to continue using digital payment service. The results of this study can be useful for digital payment service provider in order to increase service satisfaction.
\end{abstract}

Keywords: Digital Payment; Uang Digital; Dompet Elektronik; Dompet Digital; Digital Wallet

\begin{abstract}
ABSTRAK
Tren penggunaan digital payment di Indonesia semakin meningkat dari tahun ke tahun. Layanan digial payment ini telah dirasakan manfaatnya untuk semua kalangan. Penelitian ini memberikan wawasan mengenai kesadaran, persepsi dan preferensi mahasiswa di Indonesia terhadap sistem pembayaran berbasis digital. Penelitian kuantitatif ini melibatkan 104 siswa yang berasal berbagai perguruan tinggi di Indonesia. Informasi yang dikumpulkan menggunakan kuesioner dianalisisi dengan menggunakan teknik statistik deskriptif. Hasil temuan penelitian ini menunjukkan bahwa kesadaran para mahasiswa di Indonesia terkait layanan digital payment adalah sangat tinggi. Kenyamanan penggunaan layanan, ketersediaan layanan, diskon, dan poin hadiah menjadi faktor-faktor utama yang mempengaruhi mereka dalam memilih layanan digital payment. Hasil temuan penelitian juga menunjukkan bahwa mayoritas siswa lebih memilih untuk terus menggunakan layanan digital payment. Hasil penelitian ini dapat bermanfaat bagi penyedia layanan digital payment dalam rangka meningkatkan kepuasan layanan.
\end{abstract}

Kata kunci: Digital Payment; Uang Digital; Dompet Elektronik; Dompet Digital; Digital Wallet 


\section{PENDAHULUAN}

Produk baru yang lebih efektif dan efisien dalam penggunaan selalu kita cari walaupun kita sudah mempunyai kebiasaan dalam mengkonsumsi sehari-hari, oleh karenanya perusahaaan selalu mencari peluang bisnis baru, dan terkadang peluang baru ini memicu perubahan yang besar, seperti halnya system pembayaran dimana kita terbiasa membeli suatu produk lalu membayar dengan uang tunai berupa lembaran kertas atau kepingan logam yang disimpan dalam dompet, perubahan yang terjadi sekarang adalah bentuk uang tunai yang berada dalam dompet elektronik yang dapat digunakan menggunakan smartphone, kita dapat melakukan pembayaran secara digital, atau dikenal dengan istilah digital payment.

Digital payment merupakan layanan elektronik untuk menyimpan data instrumen pembayaran sebagai alat pembayaran dengan menggunakan kartu dan/atau uang elektronik, yang dapat juga menampung dana, untuk melakukan pembayaran (Bank Indonesia, 2016) yang dirancang untuk menawarkan kecepatan, kemudahan penggunaan, efisiensi, efektivitas, transparansi, dan aksesibilitas kepada pelanggan. Layanan ini sangan cocok di Indonesia karena populasi penduduk Indonesia yang luas dan aplikasi digital payment yang disediakan perusahaan berbasis internet meningkat 50\% dari Q4 2017 hingga Q2 2019 (iprice, n.d.), dimana uang elektronik tersebut disimpan pada dompet digital yang dikembangkan oleh sebuah aplikasi.

Aplikasi digital payment memungkinkan pengguna untuk membayar, memeriksa saldo, dan mentransfer uang secara instan. Penyedia aplikasi digital payment di Indonesia bukan hanya dari sector perbankan, tetapi berasal dari berbagai sector seperti perusahaan telekomunikasi, perusahaan treansportasi, dan perusahaan pemula digital. Bukan hanya jumlah aplikasinya saja yang meningkat tetapi jumlah transaksi uang elektronik di Indonesia terus menunjukkan peningkatan dari tahun ke tahun, pada tahun 2010 jumlah transaksi uang elektronik baru mencapai 7,9 juta unit, dengan total transaksi Rp 693,47 miliar, dan sampai dengan tahun 2019 jumlah transaksi uang elektronik mencapai 31 kali lipat menjadi 25,1 juta unit, dengan nilai transaksi mencapai Rp 95,75 triliyun (Kusnandar, 2019).

Transaksi uang elektronik ini dijalankan oleh Perusahaan Penyelenggara Jasa Pembayaran (PPJP) dengan mengikuti aturan Bank Indonesia No.18/21/DKSP perihal Penyelenggaraan uang elektonik (Electronic Money). PPJP menggabungkan konsep kartu kredit / debit dengan uang tunai dalam smartphone untuk dapat melakukan transaksi uang elektronik di toko khusus, dengan menggunakan teknologi berbasis Short Message Service (SMS), mobile, web, subscriber identity module tool kit, dan/atau unstructured supplementary service data (Bank Indonesia, 2016). Pada awal tahun 2020 ada 10 (sepuluh) PPJP yang telah 
terdaftar pemrosesan transaksi dengan QRIS (Quick Respond Code Indonesian Standard) (Indonesia, 2020), sbb:

\section{Shopeepay}

ShopeePay merupakan layanan uang elektronik yang digunakan sebagai metode pembayaran online di aplikasi Shopee, offline di merchant ShopeePay, dan untuk menyimpan pengembalian dana yang diselenggarakan oleh PT Airpay International Indonesia, yang merupakan anak usaha dari Shopee Indonesia, Shopee merupakan platform e-commerce terkemuka di Asia Tenggara dan Taiwan, sejak tahun 2015 dan berkantor pusat di Singapura (Shopee, n.d.).

\section{Gopay}

Gopay merupakan dompet elektronik untuk menyimpan GoJek Credit yang bisa digunakan untuk membayar transaksi-transaksi yang berkaitan dengan layanan di dalam aplikasi Gojek. Gojek mulai tahun 2010 sampai sekarang menjadi salah satu platform teknologi terbesar di Asia Tenggara.Gopay merupakan produk dari PT Dompet Karya Anak bangsa atau sering disebut dengan DOKAB, yang merupakan anak perusahaan Gojek yang berkantor pusat di Jakarta (Gojek, n.d.)

Dana

DANA atau Digital payment Indonesia merupakan layanan aplikasi digital payment dari PT Espay Debit Indonesia Koe yang merupakan hasil kerjasama Emtek group dan Ant Financial, dengan kantor pusat di Surabaya merupakan aplikasi digital payment resmi yang bisa digunakan untuk transaksi di e-commerce Bukalapak melalui BukaDompet dan mulai beroperasi tahun 2017 (Gumiwang, 2019)

Linkaja

LinkAja adalah layanan keuangan elektronik berbasis aplikasi dari PT Fintek Karya Nusantara yang berkantor pusat di Jakarta dan beroperasi mulai 2019 yang didirikan oleh Telkomsel bersama anggota Badan Usaha Milik Negara lainnya, yaitu Bank Mandiri, Bank $\underline{\text { Negara Indonesia, Bank Rakyat Indonesia, Bank Tabungan Negara, Pertamina, Asuransi }}$ Jiwasraya dan Danareksa (LinkAja, n.d.).

Qren

QRen merupakan layanan yang menghubungkan penjual (Merchant) dengan penerbit alat bayar (Issuer) untuk memberikan kemudahan bagi pembeli dalam melakukan pembayaran 
secara mobile dengan dengan menggunakan teknologi QR (Quick Response) code yang merupakan produk dari PT Telekomunikasi Indonesia, Tbk. (qren, n.d.)

Paytren

Paytren merupakan produk dari PT. Veritra Sentosa Internasional yang berkedudukan di Bandung, Paytren dikenal oleh masyarakat karena pendirinya yaitu Ustad Yusuf Mansyur. (Paytren, n.d.)

Ovo

Ovo merupakan aplikasi pembayaran untuk transaksi finansial dengan nama OVO Cash dan pengumpulan poin dengan nama OVO points yang dapat digunakan Kembali sebagai alat pembayaran didirikan oleh PT. Visionet Internasional.

OttoCash

Ottocash merupakan uang elektronik dari PT Transaksi Artha Gemilang, dibawah OttoPay Bersama dengan iSaku dan Pede. OttoPay sendiri adalah layanan terafiliasi Salim Group yang resmi beroperasi di tahun 2018, yang memposisikan diri sebagai payment aggregator via kode QR dari berbagai penyedia e-money yang sudah bekerja sama (Nabila, 2019)

\section{Bluepay Cash}

Bluepay Cash merupakan saldo dari Bluepay Wallet, didirikan PT BluePay Digital Internasional di Jakarta, dengan dukungan BluePay Group yaitu perusahaan Fintech yang berkantor pusat di Bankok. Bluepay Cash sendiri mendapatkan lisensi dari Bak Indonesia tahun 2018 (BluePay Dapatkan Lisensi Uang Elektronik Bank Indonesia (UPDATED), n.d.).

Dokupay

Doku dari PT Nusa Inti Artha merupakan perusahaan business to business (B2B) yang telah hadir di tahun 2007, sebagian besar transaksi dihasilkan dari produk dan layanan payment gateway, transfer service, dan value added service lainnya, dan di tahun 2013 mulai diluncurkannya Dokupay (Kontan, 2020)

Perusahaan penyelenggara jasa pembayaran di Indonesia atau kita lebih kenal dengan istilah fintech sampai dengan pertengahan tahun 2020 berjumlah 51 (lima puluh satu) perusahaan yang telah mendapatkan izin dari bank Indonesia, termasuk kesepuluh perusahaan diatas. Dukungan pemerintah dalam praktik pembayaran digital sangat baik, ditambah dengan kemudahan penggunaan dalam transaksi hal ini merupakan kekuatan dalam bertransaksi secara 
digital (iradianty \& Rustono, 2015; Arianti dan Darma, 2019), dengan keadaan yang sangat memungkinkan untuk bertransaksi secara digital, kesadaran dari masyarakat untuk melakukan perubahan dari yang biasanya bertransaksi secara tunai berubah menjadi non tunai tidaklah mudah.

Penelitian sebelumnya dilakukan Kepada Generasi Millenial, mereka lebih memilih bertransaksi secara digital dibandingkan dengan uang tunai (Houston, 2019) penerapan aplikasi digital payment berdampak positif, seperti kemudahan bertransaksi, praktis ada cashback, diskon, lebih aman (Badri, 2020) mudah digunakan dan bisa diterima di berbagai tempat, terutama Gopay (ipos, 2020) selain itu dapat meminimalisir terjadinya inflasi akibat banyaknya uang beredar di masyarakat (Tarantang, Awwaliyah, Astuti, \& Munawaroh, 2019). Penggunaan aplikasi digital Payment dilakukan untuk berbagai hal seperti transportasi online, membeli makanan, tiket, dsb (Houston, 2019) memberikan banyak keuntungan daripada menggunakan metode pembayaran konvensional (Mun, Khalid, \& Nadarajah, 2017; Kusuma dan Darma, 2020).

Pilihan metode pembayaran dapat mengacu pada Teori pilihan konsumen yang menggambarkan perilaku konsumen pareto, kategori dasar yang digunakan oleh teori ini adalah konsumen, pendapatan konsumen, preferensi konsumen dan kegunaan, pilihan konsumen didasarkan pada preferensi pribadi mereka dan peran ekonom adalah untuk memahami apa yang mempengaruhi preferensi dalam pemilihan konsumen (Swiecka, Terefenko, \& Paprotny, 2021; Danuarta dan Darma, 2019). Preferensi konsumen berkorelasi dengan atribut demografi dan pendapatan, tetapi juga bervariasi menurut nilai dan jenis transaksinya termasuk metode pembayaran berdasarkan peran diskon dan biaya tambahan, selain itu pilihan metode pembayaran sangat dipengaruhi oleh preferensi individu konsumen, tetapi pengarahan oleh pedagang mungkin efektif dalam beberapa keadaan (Stavins, 2018).

Pembayaran digital yang disediakan oleh perusahaan penjelenggaran jasa pembayaran berbasis teknologi yang kita sebut juga digital payment merupakan perusahaan yang termasuk dalam industry keuangan, tetapi tidak terbatas dari perusahaan perbankan, pemain dalam bisnis ini berupa perusahaan bank ataupun non bank, yang memanfaatkan ketersediaan internet, kemudahan komunikasi baik dari sisi konsumen maupun dari penyedia karena media yang digunakan memungkinkan transaksi dilaksanakan secara otomatis, selain itu transaksi semakin sering dilakukan karena ketersediian layanan yang diberikan penyedia berkat kerja sama dengan berbagai pihak, seperti toko online dan toko offline.

Meningkatnya jumlah transaksi didasarkan oleh factor demographi serta meningkatnya literasi keuangan masyarakat menjadi faktor utama terjadinya peningkatan transaksi 
(Kusnandar, 2019). Sementara layanan yang paling banyak diberikan oleh perusahaan terbebut adalah pembayaran retail offline (iprice, n.d.). Perusahaan penyedia digital payment tersebut sering kita dengar dengan perusahaan financial technology (fintech). Financial technology (fintech) merupakan suatu perusahaan yang melibatkan beberapa aspek industri keuangan dan di mana aspek utama dari model bisnisnya adalah digital (Beaumont, 2020) dengan memanfaatkan ketersediaan komunikasi, keberadaan internet, dan pemrosesan informasi secara otomatis (Milian, Spinola, \& de Carvalho, 2019; Putra dan Darma, 2019).

Fintech bisnis model yang dijalankan antara lain: (1) menjalin hubungan antara manajemen perusahaan dengan toko online dan offline, (2) menciptakan kemitraan untuk saling melengkapi dan memberikan nilai, dan (3) intergrasi dan penggunaan teknologi mobile front-end (Jocevski, Ghezzi, \& Niklas, 2020; Ferdiana dan Darma, 2019). Perusahaan ini saling bersaing untuk mendapatkan konsumen dengan meningkatkan pengalaman menggunakan (user experiment) konsumen, promosi yang lebih kreatif yang bercirikan gaya hidup, meningkatkan keamanan biometric, serta meningkatkan kecepatan bertransaksi, dan focus langsung pada solusi dari suatu masalah dan menghabiskan seluruh energi untuk menyelesaikannya, berbeda dengan Bank secara konvensional yang umumnya tidak dapat focus pada masalah tertentu (Acar \& Citak, 2019; Mahyuni et al, 2020).

Pemasaran dari mulut ke mulut adalah pendorong penting perilaku konsumen menggunakan digital payment, selain itu keuntungan relatif, kompatibilitas, kompleksitas, dan kemampuan pengamatan juga mendorong niat masyarakat untuk menggunakan layanan ini (Kaur, Dhir, Bodhi, Singh, \& Almotairi, 2020; Adnyasuari dan Darma, 2017) untuk digunakan pada berbagai layanan seperti transportasi, telekomunikasi, entertainment, asuransi, , investasi, logistic, makanan, kesehatan, kegiatan donasi, transfer uang secara instan melalui aplikasi, pembayaran tagihan bulanan dan penarikan tunai. Pemasarannya pun dilakukan dengan selalu meningkatkan ketersediaan layanan, discount produk dan jasa layanan, serta adanya hadiah.

\section{METODE PENELITIAN}

Penelitian ini menggunakan pendekatan penelitian kuantitatif dengan cara survei. Survei dilakukan dengan menggunakan bantual kusioner secara online terhadap mahasiswa di Indonesia. Pengambilan sampel untuk pengumpulan data di lakukan dengan menggunakan teknik random sampling. Adapun ukuran sampel dalam penelitian ini adalah 104 mahasiswa. Hasil pengumpulan data kemudian dianalisis menggunakan aplikasi spreadsheet. 


\section{HASIL DAN PEMBAHASAN}

\section{Tabel 1. Profil responden}

$\begin{array}{ccc}\text { Jenis Kelamin } & \text { Jumlah } & \text { Persentase } \\ \text { Perempuan } & 50 & 48.08 \% \\ \text { Laki-laki } & 54 & 51.92 \%\end{array}$

Sumber : Data Diolah

Tabel 1. Profil responden memperlihatkan bahwa jumlah mahasiswa perempuan tidak jauh berbeda dengan jumlah mahasiswa laki-laki. Hal ini menunjukkan bahwa kedua kelompok tersebut memiliki proporsi yang seimbang.

\section{Tabel 2. Kesadaran tentang digital payment}

\begin{tabular}{|c|c|c|c|}
\hline Level & Kesadaran digital payment & Jumlah & Persentase \\
\hline 0 & Saya tidak mengetauhi tentang layanan digital payment & 0 & $0 \%$ \\
\hline 1 & $\begin{array}{l}\text { Saya tidak begitu mengetahui tentang layanan digital } \\
\text { payment }\end{array}$ & 1 & $0.96 \%$ \\
\hline 2 & Saya sedikit mengetahui tentang layanan digital payment & 6 & $5.77 \%$ \\
\hline 3 & Saya cukup mengetahui tentang layanan digital payment & 43 & $41.35 \%$ \\
\hline 4 & Saya sangat mengetahui tentang layanan digital payment & 54 & $51.92 \%$ \\
\hline
\end{tabular}

Sumber : Data Diolah

Berdasarkan 104 sampel mahasiswa, didapat bahwa kesadaran mahasiswa terhadap layanan digital payment relatif sangat tinggi, yaitu 93.27\% mahasiswa telah memiliki tingkat kesadaran yang baik tentang layanan digital payment, sementara 5.77\% mahasiswa memiliki tingkat kesadaran yang kurang tentang layanan digital payment, dan $0.96 \%$ mahasiswa memiliki tingkat kesadaran yang sangat kurang tentang layanan digital payment. 
Tabel 3. Kesadaran dan pilihan terhadap perusahaan penyelenggara digital payment

Aplikasi penyedia layanan

GoPay

Ovo

Qren

Link Aja

Dana

Paytren

Shopeepay

BluePay

Ottocash

DOKU
Awareness

Jumlah Persentase

104

104

92

100

102

84

101

68

61

73

$100 \%$

$100 \%$

$88,46 \%$

$96,15 \%$

$98,08 \%$

$80,77 \%$

$97,12 \%$

$65,38 \%$

$58,65 \%$

$70,19 \%$
Preference

Jumlah Persentase

90

$86,54 \%$

87

$83,65 \%$

52

$50,00 \%$

52

$50,00 \%$

59

$56,73 \%$

$25,00 \%$

$66,35 \%$

$27,88 \%$

$26,92 \%$

$29,81 \%$

Sumber : Data Diolah

Tabel 3 menunjukkan bahwa dari sampel mahasiswa yang telah didapat, kesadaran mahasiswa tentang perusahaan penyedia layanan digital payment, Go Pay dan Ovo adalah dua penyedia digital payment teratas, menurut mereka 100 persen responden yang disurvei dalam penelitian ini telah mengetahui tentang kedua provider ini, diikuti oleh Dana, Shopee dan Link Aja dengan persentase berturut-turut 98.08 persen, 97.12 persen, dan 96.15 persen. Tabel 3 juga menunjukkan bahwa Gopay dan Ovo adalah dua produk yang paling banyak disukai untuk digunakan oleh para mahasiswa dengan 86.54 persen dan 83.65 persen, diikuti oleh Shoppepay, Dana, Qren, dan Linkaja dengan 66.35 persen, 56.73 persen, 50 persen dan 50 persen.

Tabel 4. Alasan untuk menggunakan suatu layanan digital payment

\begin{tabular}{clcc} 
No & \multicolumn{1}{c}{ Alasan } & Jumlah & Ranking \\
1 & Ketersediaan layanan & 66 & 2 \\
2 & Kenyamanan layanan & 77 & 1 \\
3 & Keamanan Pembayaran & 50 & 5 \\
4 & Penerimaan layanan di berbagai toko & 50 & 6 \\
5 & Memanfaatkan poin/hadiah & 53 & 4 \\
6 & Discount & 61 & 3 \\
7 & Lainnya & 13 & 6
\end{tabular}

Sumber : Data Diolah 
Tabel 4 diatas menunjukkan bahwa kenyamanan layanan sebagai alasan yang paling penting bagi para mahasiswa untuk menggunakan digital payment, diikuti oleh ketersediaan layanan, diskon, dan hadiah. Keamanan pembayaran dan penerimaan layanan menjadi alasan selanjutnya yang menjadi pertimbangan para mahasiswa dalam penggunaan layanan digital payment.

\section{Tabel 5. Frekuensi menggunakan layanan digital payment (per bulan)}

$\begin{array}{lcc}\text { Frekuensi (per bulan) } & \text { Jumlah } & \text { Persentase } \\ \text { Kurang dari 1 kali } & 0 & 0 \% \\ \text { 1-4 kali } & 26 & 25 \% \\ \text { 5-8 kali } & 58 & 55.77 \% \\ \text { Lebih dari 8 kali } & 20 & 19.23 \%\end{array}$

Sumber : Data Diolah

Tabel 5 menunjukkan bahwa 55.77 persen mahasiswa menggunakan layanan digital payment 5-8 (lima sampai dengan delapan) kali dalam sebuan dan 25 persen mahasiswa menggunakan 1-4 (satu sampai empat) kali sebulan diikuti 19.23 persen mahasiswa yang disurvei menggunakan layanan digital payment lebih dari 8 (delapan) kali sebulan.

Tabel 6. Kepuasaan terhadap layanan digital payment

$\begin{array}{lll} & \text { Jumlah } & \text { Persentase } \\ \text { Sangat Puas } & 13 & 12.5 \% \\ \text { Puas } & 46 & 44.23 \% \\ \text { Netral } & 29 & 27.88 \% \\ \text { Tidak Puas } & 16 & 15.38 \% \\ \text { Sangat Tidak Puas } & 0 & 0 \% \\ \text { Sumber : Data Diolah } & & \end{array}$

Tabel 6 menunjukkan bahwa 12.4 persen siswa sangat puas dengan layanan digital payment yang disediakan oleh perusahaan penyedia layanan dan 44.23 persen siswa puas, sedangkan 27.88 persen beropini netral. Terdapat 15.38 persen siswa yang menyatakan tidak puas dengan layanan digital payment. 
Tabel 7. Kendala selama menggunakan layanan digital payment

$\begin{array}{lcc} & \text { Jumlah } & \text { Persentase } \\ \text { Terkendala } & 74 & 71.15 \% \\ \text { Tidak Terkendala } & 30 & 28.85 \%\end{array}$

Sumber : Data Diolah

Tabel 7 menunjukkan bahwa 71.15\% mahasiswa masih menemukan kendala saat menggunkan layanan digital payment yang disediakan perusahaan jasa penyelenggara, sementara $30 \%$ mahasiswa belum menemukan hambatan.

\section{Tabel 8. Preferensi untuk tetap menggunakan layanan digital payment}

$\begin{array}{lcc} & \text { Jumlah } & \text { Persentase } \\ \text { Sangat Mungkin } & 54 & 51.92 \% \\ \text { Mungkin } & 33 & 31.73 \% \\ \text { Netral } & 17 & 16.35 \% \\ \text { Mungkin Tidak } & 0 & 0 \% \\ \text { Saya Berhenti } & 0 & 0 \%\end{array}$

Sumber : Data Diolah

Tabel 8. menunjukkan bahwa 51.92 persen mahasiswa lebih suka untuk terus menggunakan layanan digital payment dan 31.73 persen mahasiswa cenderung bersedia untuk tetap menggunakannya, sementara 16.35 persen mahasiswa berpendapat bahwa mereka netral.

\section{PENUTUP}

Kesadaran para mahasiswa tentang layanan digital payment sangat tinggi, dan mahasiswa sangat mengetahui tentang layanan digital payment, penyedia layanan yang paling popular dari hasil penelitian ini adalah berturut-turut Gopay, Ovo, Dana, Shopee dan LinkAja. Faktor kenyamanan penggunaan layanan merupakan alasan utama sering menggunakan, dengan frekuensi penggunaan dalam sebulan sebanyak 5 sampai dengan 8 kali, walaupun demikian mahasiswa sering menemukan kendala terhadap layanan digital payment ini, diharapkan penelitian selanjutnya dapat meneliti terkait kendala-kendala yang dihadapi oleh pengguna terhadap layanan. 


\section{DAFTAR PUSTAKA}

Acar, O., \& Citak, Y. E. (2019). Fintech Integration Process Suggestion for Banks. Procedia, 971-978. $\quad$ Retrieved from https://reader.elsevier.com/reader/sd/pii/S1877050919313092?token=3584750E9EF467 AFF56C98DD63F4E7953FC42A43214BF62E87A87A88A941B9286A1BDE2B812E E6335199CD308E21444E.

Adnyasuari, P.A.S., and Darma, G.S. (2017). Technology Acceptance Model dan ESatisfaction in Mobile Banking, Jurnal Manajemen \& Bisnis, 14 (2): 1-12.

Arianti, N.L.N., Darma, G.S., and Mahyuni, L.P. (2019). Menakar Keraguan Penggunaan QR Code Dalam Transaksi Bisnis, Jurnal Manajemen \& Bisnis, 16 (2): 67-78.

Badri, M. (2020). Adopsi Inovasi Aplikasi Dompet Digital di Kota Pekanbaru. INOVBIZ, 8, 120-127.

Bank Indonesia, P. (2016). Penyelenggaraan pemrosesan transaksi pembayaran. Bank Indonesia. Retrieved 2020, from https://www.bi.go.id/id/peraturan/sistempembayaran/Pages/pbi_184016.aspx

Beaumont, P. (2020). Digital Finance. New York: Routledge.

Daily Social. (n.d.). (Daily Social) Retrieved 2020, from https://dailysocial.id/post/lisensi-emoney-bluepay.

Danuarta, G.L.N., and Darma, G.S. (2019). Determinants of Using Go-Pay and Its Impact on Net Benefits, International Journal of Innovative Science and Research Technology, 4 (11): 173-182.

Ferdiana, A.M.K., and Darma, G.S. (2019). Understanding Fintech Through Go-Pay, International Journal of Innovative Science and Research Technology, 4 (2): 257-260.

Gojek. (n.d.). Retrieved from https://www.gojek.com/gopay/

Gumiwang, R. (2019, August 20). Tirto.id. (I. L. Bhaskara, Editor, \& Tirto.id) Retrieved July 28, 2020, from https://tirto.id/geliat-dana-di-bawah-dominasi-gopay-dan-ovo-egmo

Houston, D. D. (2019). Adopsi Penerimaan Digital Payment Pada Kalangan Milenial. Medium, 7(2). Retrieved from https://journal.uir.ac.id/index.php/Medium/article/view/4094/2324 Indonesia, B. (2020). Sosialisasi QRIS. Jakarta: Bank Indonesia.

ipos. (2020). Evolusi Industri Dompet Digital. ipos. Retrieved from https://www.ipsos.com/sites/default/files/ct/news/documents/202002/ipsos_media_conferennce_-_e-wallet_-_id_0.pdf

iprice. (n.d.). Retrieved Juli 2020, from https://iprice.co.id/trend/insights/e-wallet-terbaik-diindonesia/ 
iradianty, A., \& Rustono, A. (2015). SWOT Analysis Of Telco Branchless Banking In Indonesia. The 6th Seminar \& Conference on Business \& Technology in ICT Industry (SCBTII 2015) (p. 61). Jakarta: Telkom University.

Jocevski, M., Ghezzi, A., \& Niklas, A. (2020, April). Exploring the growth challenge of mobile payment platforms: A business model perspective. Electronic Commerce Research and Applications, 40.

Kaur, P., Dhir, A., Bodhi, R., Singh, T., \& Almotairi, M. (2020, September). Why do people use and recommend m-wallets? Journal of Retailing and Consumer Services, 56. doi:https://doi.org/10.1016/j.jretconser.2020.102091

Kontan. (2020, Mei). Retrieved July 2020, from https://keuangan.kontan.co.id/news/pengguna-doku-e-wallet-capai-3-juta-dokuoptimalkan-beberapa-produk

Kusnandar, V. B. (2019, 11 4). KataData. Retrieved from DataBox: https://databoks.katadata.co.id/datapublish/2019/11/07/berapa-transaksi-uangelektronik-di-indonesia.

Kusuma, P. O., \& Darma, G. S. (2020). Mobile Payment Transaction on MSMEs. International Research Journal of Management, IT \& Social Sciences, 7(3), 104-109. https://doi.org/10.21744/irjmis.v7n3.926

LinkAja. (n.d.). Retrieved from https://www.linkaja.id/

Milian, E., Spinola, M., \& de Carvalho, M. (2019, April). Fintechs: A literature review and research agenda. Electronic Commerce Research and Applications, 34. Retrieved 2020

Mun, Y. P., Khalid, H., \& Nadarajah, D. (2017). Millenial's Perception on Mobile Payment Service in Malaysia. Procedia, 124, 397-404.

Mahyuni, L.P., Adrian, R., Darma, G.S., Krisnawijaya, N.N.K., Dewi, I.G.A.A.P., and Permana, G.P.L. (2020). Mapping the potentials of blockchain in improving supply chain performance, Cogent Business \& Management, 7 (1788329): 1-18. https://doi.org/10.1080/23311975.2020.1788329

Nabila, M. (2019, March 27). Layanan Fintech Salim Group “OttoPay” Percepat Usaha Mikro Adopsi Pembayaran Digital. (B. Hartono, Interviewer) Retrieved from https://dailysocial.id/post/ottopay-payment-aggregator-ukm-pembayaran-digital

Putra, I.G.N.A.P., and Darma, G.S. (2019). Is Bitcoin Accepted in Indonesia? , International Journal of Innovative Science and Research Technology, 4 (2): 424-430.

Paytren. (n.d.). Retrieved from https://www.paytren.co.id/ qren. (n.d.). Retrieved from https://qren.tmoney.co.id/about 
Shopee. (n.d.). Retrieved from https://shopee-help.force.com/s/

Stavins, J. (2018). Consumer preferences for payment methods: Role of discounts and surcharge. Journal of Banking and Finance, 94, 35-53. Retrieved from https://www.sciencedirect.com/science/article/abs/pii/S0378426618301390

Swiecka, B., Terefenko, P., \& Paprotny, D. (2021). Transaction factor's influence on the choice of payment bu Polish Consumers. Journal of Retailing and Consumer Service. Retrieved from https://reader.elsevier.com/reader/sd/pii/S0969698920312728?token=D11ECFD0229 F42346D214D4D01939ABC6394F160F622A81932EC9758819E9E8DF513E67F941 4718A1EC2C4B5E75A1F66

Tarantang, J., Awwaliyah, A., Astuti, M., \& Munawaroh, M. (2019, Juli). Perkembangan Sistem Pembayaran Digital Pada Era Revolusi Industri 4.0 di Indonesia. Jurnal Al Qardh, 4. 